\title{
Eski Türk Edebiyatı Çalışmalarında Dijital Kaynaklar ve Uygulamalar
}

\section{Digital Resources and Applications in Old Turkish Literature Studies}

\author{
Necati işLER \\ Dr., Öğretmen, Maltepe Ortaokulu \\ PhD., Teacher, Maltepe Secondary School \\ Ankara, Turkey \\ necatiisler76@gmail.com \\ orcid.org/0000-0001-9645-8320
}

\author{
Makale Bilgisi / Article Information

$\begin{array}{ll}\text { Makale Türü / Article Types } & \text { : Araştırma Makalesi / Research Article } \\ \text { Geliş Tarihi / Received } & : 23 \text { Mart / March } 2021 \\ \text { Kabul Tarihi / Accepted } & : 1 \text { Mayıs / May } 2021 \\ \text { Yayın Tarihi / Published } & : 15 \text { Haziran / June } 2021 \\ \text { Yayın Sezonu / Pub Date Season } & \text { : Haziran / June } \\ \text { Cilt / Volume: } 8 \text { - Sayı / Issue: } 1 \text { - Sayfa / Pages: 249-272 }\end{array}$

Atıf / Cite as

İşler, Necati. "Eski Türk Edebiyatı Çalışmalarında Dijital Kaynaklar ve Uygulamalar". Bülent Ecevit Üniversitesi Illahiyat Fakültesi Dergisi 8/1 (2021), 249-272.

Doi: $10.33460 /$ beuifd. 902116

İntihal / Plagiarism

Bu makale, en az iki hakem tarafından incelendi ve intihal içermediği teyit edildi.

This article has been reviewed by at least two referees and scanned via a plagiarism software.

Yayın Hakkı / Copyright ${ }^{\circ}$

Zonguldak Bülent Ecevit Üniversitesi, İlahiyat Fakültesi tarafından yayınlanmıştır. Tüm hakları saklıdır.

Published by Zonguldak Bulent Ecevit University, Faculty of Theology, Zonguldak, Turkey. All rights reserved.

Öz: Geçmişte ilim için yollara düşenleri, gerçek mekânlar ve kütüphaneler beklemekteydi. Uzun süren yolculukların ardından kitaba dokunuluyor ve kitap hissediliyordu. Bilgisayar ve internet çağının araştırmacıları olarak bizler ise, klavyemizin tuşlarına basarak ya da ekranlarımıza işaret parmağımızla dokunarak işe başlıyoruz. ilim yolculuğumuza "1" ve "O"larla döşenmiş dijital yollarda devam ediyoruz. Bu makalemizde ele alacağımız dijital (sayısal) kaynaklar, internet vasıtasıyla bize sunulan içeriklerdir. Veri tabanları, ansiklopediler, kitaplar, süreli yayınlar, makaleler, tezler, elektronik kitaplar akademik çalışmada öncelikli dijital kaynaklardandır. Günümüzde kapsayıcı ve detaylı bir akademik çalışma, online ortamda geniş bir taramayı gerekli kılmaktadır. Bilgisayar ve internet teknolojisinin daha yoğun bir şekilde kullanılmaya başlanmasıyla araştırmacılar için yeni bir ihtiyaç ortaya çıkmıştır. Sadece kaynakların değil, öğretimin de sanal ortama taşındığı günümüzde dijital araçlara erişim ve dijital araçların kullanımı daha fazla önem kazanmıştır. Eski Türk Edebiyatı alanında yayın ya da tez çalışması yapmak isteyen bir araştırmacı için literatür taraması, el yazma eserlere erişim, kataloglardaki kayıt yanlışları, dijital sözlüklere erişim, Microsoft Word'de metin transkripsiyonu gibi 
hususlar önem arz etmektedir. Daha çok kaynağa, daha hızlı ve doğru yollardan ulaşmak, akademik bir çalışma için artık vazgeçilmez hâle gelmiştir. Bu makalemizde, dijital kaynaklar ve onların Eski Türk Edebiyatı çalışmalarında kullanımı örnekleriyle ele alınacaktır. Ayrıca Microsoft Word ile metin transkripsiyonu yaparken dikkat edilmesi gereken hususlar üzerinde durulacaktır.

Anahtar Kelimeler: Eski Türk Edebiyatı, Dijital Kaynaklar, Literatür Taraması, El Yazması Eserler, Kataloglardaki Kayıt Yanlışları, Dijital Sözlükler, Microsoft Word, Metin Transkripsiyonu.

Abstract: In the past, real places and dusty shelves of libraries awaited those who hit the road for science. Journeys lasting months were made by riding horses and camels. The book was touched, the book felt. As researchers of the computer and internet age, we start by pressing the keys of our keyboard or by touching our screens with our forefinger. We continue our journey of knowledge on digital roads paved with " 1 " and " 0 ". The digital resources that we will consider in this article are the content offered to us via the internet. Databases, encyclopedias, books, periodicals, articles, theses, electronic books are among the priority digital resources in academic study. Today, an inclusive and detailed academic study requires extensive research in the online environment. With the more intensive use of computer and internet technology, a new need has arisen for researchers. Access to digital tools and the use of digital tools have become more important in today's world, where not only resources but also teaching are transferred to the virtual environment. For a researcher who wants to make a publication or thesis in the field of Old Turkish Literature, issues such as literature review, access to manuscripts, record errors in catalogs, access to digital dictionaries, text transcription in Microsoft Word are important. Reaching more resources in faster and more accurate ways has become indispensable for an academic study. In this article, the use of digital resources in Old Turkish Literature studies will be discussed through examples. In addition, the issues that need to be considered about text transcription with Microsoft Word will be emphasized.

Keywords: Old Turkish Literature, Digital Resources, Literature Review, Manuscripts, Record Errors in Catalogs, Digital Dictionaries, Microsoft Word, Text Transcription.

\section{Giriş}

Eski Türk Edebiyatı alanında çalışanlar için Mertol Tulum'un Tarihi Metin Çalışmalarında Usûl, M. Fatih Köksal'ın Eski Türk Edebiyatında Tenkit ve Teori ve Selami Ece'nin Klasik Türk Edebiyatı Araştırma Yöntemleri kitabı usûl açısından temel eserler niteliğindedir. Bu eserlerin dışında İsmail Ünver'in "Çevriyazıda Yazım Birliği Üzerine Öneriler" makalesi de metin odaklı çalışanlar için vazgeçilmez başvuru kaynağı olmuştur. Bu çalışmalar dışında araştırma metot ve teknikleri ile ilgili pek çok kıymetli çalışma vardır. Usûl konusundaki ihtiyaçları karşılayan bu çalışmaların dışında, bilgisayar ve internet teknolojisinin daha yoğun bir şekilde kullanılmaya başlanmasıyla araştırmacılar için yeni bir ihtiyaç daha ortaya çıkmıştır. 
Sadece kaynakların değil, öğretimin de sanal ortama taşındığı günümüzde dijital araçlara erişim ve dijital araçların kullanımı daha fazla önem kazanmıştır. Daha çok kaynağa, daha hızlı ve doğru yollardan ulaşmak, akademik bir çalışma için artık vazgeçilmez hale gelmiştir.

Dijital kaynaklar, internet vasıtasıyla bize sunulan içeriklerdir. ${ }^{1}$ Veri tabanları, ansiklopediler, kitaplar, süreli yayınlar, makaleler, tezler, elektronik kitaplar akademik çalışmada öncelikli dijital kaynaklardandır. Günümüzde kapsayıcı ve detaylı bir akademik çalışma, online ortamda geniş bir taramayı gerekli kılmaktadır. Akademik literatüre özgün katkılar ancak bu şekilde mümkün olabilecektir. Eski Türk Edebiyatı alanında yayın ya da tez çalışması yapmak isteyen bir araştırmacı için literatür taraması, el yazma eserlere ve dijital sözlüklere erişim, ofis araçlarının kullanımı, metin transkripsiyonu gibi hususlar önem arz etmektedir. ${ }^{2}$ Bu makalemizde bu konular örnekleriyle ele alınacaktır.

\section{Literatür Taraması İçin Dijital Kaynaklar}

Bilimsel çalışmalarda ilk ve en önemli adım literatür taramasıdır. Literatür taraması, bir konunun daha önce çalışılıp çalışılmadığını, çalışılmış ise hangi açıdan ve hangi yöntemlerle ele alındığını ortaya çıkarmayı amaçlar. ${ }^{3}$ Eski Türk Edebiyatı çalışmalarında bir eser ya da müellif hakkında bir yayın ya da tez çalışmasına başlamadan önce mutlaka geniş bir literatür çalışması yapmak gerekmektedir. Özellikle şahıs ve eser özelindeki çalışmalarda biyografik ve bibliyografik nitelikteki kaynaklardan başlanılması önem arz etmektedir. Kültür Bakanlığı'nın Metin Bankası ve E-kitap projeleri bu sahadaki ilk dijital çalışmalardır. ${ }^{4}$ Bu projelerle pek çok dîvân, mesnevî ve tezkire dijital ortamda yayımlanmıştır. Bahsedilen dijital çalışmaların dışında Türkiye'de bu sahada yapılan en önemli proje Türk Edebiyatı İsimler Sözlüğü Projesi'dir. Başlangıçtan 21. yüzyıla (1985 doğumlu) kadarki Türk Edebiyatının şair ve yazarlarını kapsayan ve 14000 maddeden oluşan bu proje 27 ciltlik bir ansiklopediye tekabül etmektedir. ${ }^{5}$ Eski Türk Edebiyatı alanında yapılacak bilimsel çalışmalarda literatür taramasına şu adreslerden başlanılabilir.

KOOPLOG, “Dijital Kaynaklar, Dijital Araçlar”, 2 Aralık 2020

2 Bilgisayar ve internet teknolojisinin edebiyat araştırmalarında kullanımıyla ilgili daha önce yapılan akademik yayınlar şunlardır: Ali Büyükaslan, "Edebiyat Araştırmalarında İnternet", Selçuk Üniversitesi Sosyal Bilimler Enstitüsü Dergisi 8 (2002), 67-86; Ilyas Yazar, "Klâsik Türk Edebiyatı Çalışmalarında Bilişim Teknolojisinden Yararlanma ve E-Kütüphane Uygulamaları", Turkish Studies 2/3 (2007), 572-584; Illyas Yazar, "Transkripsiyonlu Metinlerin Web Tabanlı Öğrenme Ortamların Kullanımına Dair Sorunlar ve Çözüm Önerileri", Turkish Studies 3/6 (2008), 733-754; Mustafa ATILA, "Klâsik Türk Edebiyatı Sahasının E-Kaynakları", VIII. Klâsik Türk Edebiyatı Sempozyumu-Alî Emîrî Hatırasına-2012 (Diyarbakır: Diyarbakır Valiliği Kültür Sanat Yayınları, 2014), 29-44; Mehmet Korkut Çeçen, "Eski Türk Edebiyatı Araştırmalarında Bilgisayar Teknolojisinin Kullanımına Dair Bazı Düşünceler", Turkish Studies, 9/9 (2014), 351-366. Ayrıca bk. Bülent Ağaoğlu, "Kamuya Açık Yerli Dijital Kaynaklar: Kitap, Dergi, Makale, Tez, Yazma, Rapor, Haber, Tutanak, Illan, Köşe Yazısı, Mevzuat, Açık Arşiv", Türk Kütüphaneciliği 27 (2013), 385-397.

3 AK, "Literatür Taraması Nedir ve Nasıl Yapılır ?", 2 Aralık 2020

4 KTB, “Son Eklenen Kitaplar", 5 Ocak 2021; ISTiNYE, “Ahmet Atillâ Şentürk", 5 Ocak 2021

5 TEIS, “Kapsam", 5 Ocak 2021 
http://teis.yesevi.edu.tr

https://www.osmanliedebiyati.com

https://www.makaleler.mkutup.gov.tr

https://tez.yok.gov.tr/UlusalTezMerkezi

https://dergipark.org.tr

https://trdizin.gov.tr

https://www.davet.org.tr

https://dergiplatformu.com

http://kaynakca.hacettepe.edu.tr

https://islamansiklopedisi.org.tr

http://ktp.isam.org.tr

https://eyayinlar.mkutup.gov.tr

https://www.tdk.gov.tr/sureli-yayinlar-veri-tabani

https://www.koha.ekutuphane.gov.tr

https://www.scholar.google.com.tr

https://www.academia.edu

Literatür taramalarında kullanılabilecek birçok veri tabanının adresine Ankara Millet Kütüphanesi vasıtasıyla ulaşılabilmektedir. E-devlet üzerinden gerçekleştirilebilecek Millet Kütüphanesi üyeliği, erişim için yeterlidir. ${ }^{6}$ Yerli ve yabancı binlerce kitaba, süreli yayına, tam metin makalelere, el yazma eserlere ve Osmanlıca matbu eserlere erişim için bu veri tabanları kullanılabilir.

\section{2. Çalışma Konu ve Taslağının Web Ortamına Yüklenmesi}

Literatür çalışmasından sonra çalışılacak konu belirlenir. Bu çalışma bazen uzun soluklu bir çalışma olabilmektedir. Çalışma konusunun ve taslağının web ortamında duyurulması, aynı çalışmanın farklı bir araştırmacı tarafından yapılmasına engel olarak emek israfının önüne geçecektir. Bu duyuru aynı zamanda yapılacak çalışmaya bilim camiasından katkı sunulmasına imkân sağlayacaktır. Çalışma taslağı ilk olarak akademisyenlerin sosyal medyası olarak bilinen academia.edu sitesine yüklenebilir.? Yapılan çalışma bir tez ise eğer, tez önerisinin kabulünden sonra e-devlet yoluyla Yök Tez Merkezi'ne "devam eden çalışma" olarak kaydedilir. Çalışma ile ilgili olarak ücretsiz blog da oluşturulabilir. ${ }^{8}$ Çalışma konusuna özel alan adı (domain) ${ }^{9}$ ya da sosyal medya hesabı açılıp çalışmanın seyri takipçilerle de paylaşılabilir. Ayrıca Hatice Aynur'un çalışmalarına dayanan Osmanlı Edebiyatı Çalışmaları Bibliyografyası Veritabanı'na ${ }^{10}$ da yüklenebilir.

6 MK, "Cumhurbaşkanlığı Millet Kütüphanesi Üye Giriş Sayfası", 5 Ocak 2021

7 ACADEMIA, "Proje ve Tezler", 7 Ocak 2021

8 MANZÛM, “Manzûm Terceme-i Şiratü'l-İslâm Mehmed B. İbrahim, Muhammed B. İbrahim”. 7 Ocak 2021

9 Örneğin; faziletname.com ya da mansurname.com alan adları METUNIC üzerinden satın almaya müsaittir. Bk. MN, “Alan Adı Uygunluğunu Kontrol Et”, 7 Ocak 2021

10 OE, “Bibliyografya”, 7 Ocak 2021 


\section{El Yazma Eserlere Erişim}

Kütüphanelerde ve dijital platformlarda binlerce el yazma eser araştırmacıları beklemektedir. Yazma eserler için Türkiye'deki en büyük dijital katalog yazmalar.gov.tr'dir. Yazmalar.gov.tr adresinden birçok yazma eserin dijital kopyası görüntülenebilmekte ve satın alınabilmektedir. Ücretsiz faydalanmak için ise dilekçe yazılması gerekmektedir. Ankara Milli Kütüphane İbn-i Sînâ salonundaki özel bilgisayardan İstanbul kütüphaneleri dahil olmak üzere yazmalar.gov.tr'de künyeleri bulunan ve dijital görüntüleri sisteme aktarılmış bulunan bütün eserlerin kopyalarına erişim sağlanabilmektedir. ${ }^{11}$ Türkiye Yazma Eserler Kurumu Başkanlığı tarafından sayısallaştırılan yazma eserlerin görüntülerine Cumhurbaşkanlığı Millet Kütüphanesi Nadir Eserler bölümündeki bilgisayarlardan da ulaşılabilmektedir. Millet kütüphanesindeki bu bölümde ayrıca 50.000 adet nadir eser ve bu eserlerin sayısallaştırılmış formlarından oluşan koleksiyon da bulunmaktadır. ${ }^{12}$

Yurt dışındaki yazmalarımıza ulaşabilme imkânları dijitalleşme ile oldukça artmıştır. Kataloglarda bulduğumuz eserler, e-posta, "ask a librarian"13 (kütüphaneciye sor) ve sistem üyeliği ${ }^{14}$ gibi farklı yöntemlerle talep edilebilmektedir. Henüz taranmamış eserlerin başından, ortasından ve sonundan önemli sayfalar ücretsiz olarak istenebilir. El yazma eserin bütünü için belirli bir ödeme yapmak gerekmektedir. Ödemenin ardından eser taranıp gönderilmektedir. Kaliforniya Üniversitesi Los Angeles Kütüphanesi Türkçe Elyazmaları Özel Koleksiyonlar ${ }^{15}$ bölümüne sistem ${ }^{16}$ üzerinden kaydolarak el yazma talebinde bulunulabilir. Türkiye'de el yazmaların dijitalleştirme çalışmaları kamu kaynaklarıyla yürütülmektedir. Avrupa ve Amerika'daki kütüphanelerdeki Türk-i̇slâm eserleri ancak ücreti mukabilinde taranıp gönderilmektedir. Şu anda yurt dışındaki el yazma eserlerimizin erişime açık olan nüshalarının daha önce akademik bir araştırmaya konu olduğunu söyleyebiliriz. Gerek yurt içindeki gerekse yurt dışındaki el yazma eser kütüphaneleri yeni satın almalarla zenginleştirilmektedirler. Bu yüzden kütüphanelerin dijital kataloglarının belli aralıklarla ziyaret edilmesi araştırmacıları yeni eserlere ulaştıracaktır.

“El yazma eser"in İngilizce karşılığı olan "manuscript" ve Arapça karşılığı olan "مخطوطات" (makhțūtāț) kelimeleri ile genel arama motorlarında ve dijital kataloglarda da eser aranabilir. Eser adının Latin ve Arap harfleri ile ayrı ayrı aranması da araştırmacıyı hedefine ulaştırabilecek seçeneklerdendir. El yazma eserlere erişim için kullanılabilecek adresler şunlardır:

\footnotetext{
11 YEK, "Yazma Eserler Portalına Ankara'dan Erişim", 10 Ocak 2021

12 MK, "Nadir Eserler Kütüphanesi", 10 Ocak 2021

13 UCLA, "Research \& Teaching Support", 10 Ocak 2021; PRINCETON, "Ask a Librarian", 10 Ocak 2021

14 PRINCETON, "Your Accounts", 10 Ocak 2021

15 OAC, "Collection of Turkish manuscripts LSC.," 10 Ocak 2021

16 OAC, "Sign In with your UCLA Logon ID", 10 Ocak 2021
} 
http://www.yazmalar.gov.tr (Türkiye Yazma Eserler Kurumu) http://www.divinity.ankara.edu.tr/?page_id=19025 (A.Ü. Illahiyat Fakültesi) https://yazmaeserler.diyanet.gov.tr (Diyanet İşleri Başkanlığı) http://yazmalardtcf.ankara.edu.tr (A.Ü. Dil Tarih ve Coğrafya Fakültesi) http://bilgimerkezi.atauni.edu.tr (Atatürk Üniversitesi) https://kutuphane.atauni.edu.tr (Atatürk Üniversitesi) http://katalog.istanbul.edu.tr (İstanbul Üniversitesi) http://ataturkkitapligi.ibb.gov.tr (İstanbul Büyük Şehir Belediyesi) https://libdigitalcollections.ku.edu.tr/digital/collection/MC/search/ (Koç Universitesi)

http://88.255.225.19:8091 (Koyunoğlu Şehir Müze ve Kütüphanesi) https://katalog.marmara.edu.tr/yordambt/yordam.php (M.Ü. Nadir Eserler Koleksiyonu)

http://kutuphane.akmb.gov.tr/opac (AKMB Matbu ve Yazma kitaplar) http://digital.ghb.ba/ghb/fulltextSearchPage.xhtml (Bosna) https://www.library.ucla.edu/location/library-special-collections (USA California)

https://oac.cdlib.org (USA - Archive of California)

https://catalog.lib.uchicago.edu/vufind/ (USA - University of Chicago Library)

http://pudl.princeton.edu/collections/pudl0032 (USA - Princeton Digital Library)

http://pudl.princeton.edu/collections/pudl0079 (USA - Princeton Digital Library)

https://www.loc.gov/manuscripts (USA - Library of Congress)

https://search.lib.umich.edu (USA - University of Michigan Library)

https://guides.lib.umich.edu/İslâmicmss (USA - University of Michigan Library)

https://library.harvard.edu/collections/Islâmic-heritage-project (USA -

Harvard Library)

https://www.aub.edu.lb/libraries/Pages/default.aspx (American University of Beirut)

http://139.141.167.32/manuscript (Kuveyt Üniversitesi)

https://www.aruc.org/en/home (Arabic Union Catalog)

https://makhtota.ksu.edu.sa/search/0 (Suudi Arabistan)

http://ecat.kfnl.gov.sa (Suudi Arabistan)

http://totfim.com/Manuscripts (İran)

http://opac.nlai.ir (İran)

http://www.darelkotob.gov.eg/ar-eg/Pages/Home.aspx (Mısır)

http://ricasdb.ioc.u-tokyo.ac.jp/daiber/db_index_eng.html (Japonya) 
https://merhav.nli.org.il/primo-explore/search?vid=NLI\&lang=en_US (İsrail) https://gallica.bnf.fr/services/engine/search/advancedSearch/ (Fransa) http://nationallibrary.bg/wp/?page_id=63306 (Bulgaristan) http://nationallibrary.bg/wp/?page_id=64749 (Bulgaristan) https://viewer.cbl.ie/viewer/browse/-/1/SORT_TITLE/DC:turkishcollection (Irlanda)

https://digital.staatsbibliothek-berlin.de (Almanya)

http://cudl.lib.cam.ac.uk/collections/İslâmic/1 (Ingiltere)

https://digital.bodleian.ox.ac.uk/ (İngiltere)

https://www.fihrist.org.uk (Ingiltere)

http://www.bl.uk/manuscripts (İngiltere)

http://digi.vatlib.it (Italya)

http://nlr.ru/manuscripts (Rusya)

http://catalog.hathitrust.org (Digital Library)

https://www.worldcat.org

http://www.aghabozorg.ir/Search.aspx

http://www.almajidcenter.org/search.php

https://www.islâmic-manuscripts.net/

https://al-furqan.com/manuscript-centre/

https://www.al-mostafa.com

https://al-mostafa.info/books/htm/disp.php

http://www.manuscriptorium.com/apps/index.php

https://www.wdl.org/en

https://alkindi.ideo-cairo.org

https://www.refaiya.uni-leipzig.de/content/index.xml

https://www.ub.uni-leipzig.de/forschungsbibliothek/digitale-sammlungen/

https://www.islamicmanuscript.org/extresources/manuscriptcatalogues.

aspx

https://blogs.cul.columbia.edu/global-studies/2019/05/28/the-muslim-

world-manuscript-project/

http://wamcp.bibalex.org/

http://international.loc.gov/intldl/malihtml/

https://asia.si.edu/collections-area/İslâmic/

https://archives.saltresearch.org/

https://down.ketabpedia.com/files/bnr/bnr47313-7.pdf

https://writing.colostate.edu/guides/page.cfm?pageid=187\&guideid=12

http://cudl.lib.cam.ac.uk/collections/islamic/1

https://www.slub-dresden.de

https://archive.org 
El yazma eserler konusunda şu anda dünya üzerinde birçok proje yürütülmektedir. ${ }^{17}$ Bu projelerde el yazma eserlerin kataloglama çalışmaları yapıldığı gibi dijitalleştirme işlemleri de gerçekleştirilmektedir.

\section{Katalog Yanlışları ya da Sehiv-nâme}

Dijital kataloglarda bir kısmı müstensihlerden kaynaklanan birçok yanlış kayıt bulunmaktadır. Bu yanlışları "Sehiv-nâme" adıyla bir araya getirecek yeni bir edebi türden bile bahsedebiliriz. Tarama yaparken eserin adı, müellifi, dili, varak sayısı gibi bilgilerin yanlış olma ihtimali her zaman dikkate alınmalıdır. Bu bakımdan doktora tez konumuzu belirleme aşamasında birçok eserin yeni nüshalarına da ulaştık. ${ }^{18}$ Bu nüshalardan bazılarının bilgilerinin kataloglara yanlış olarak girildiğini eserin içeriğine bakarak tespit ettik. Örneğin; Bursa İnebey Yazma Eser Kütüphanesi, Orhan Camii Koleksiyonu'nda "16 Or 697" arşiv numarası ile kaydedilmiş bir eser vardır. Müellif adı "Alî Sırrî İznikî" olarak yazılmıştır. Eserin içerisinde yer alan bir bölüme bakılarak eser adı sehven "Sırrü'l-Erkân" olarak kaydedilmiştir. Bu eser, İbrâhim Tennûrî'nin (ö. 887/1482) Gülzâr-ı Mânevî adlı eserinin yeni bir nüshasıdır. ${ }^{19}$ Örneğin, "Kâfiye-nâme" 20 adıyla Farsça olarak kaydedilen başka bir eser, detaylı incelendiğinde Yemînî́nin Fazîletnâme'si²1 ile Niyâzî'nin Mansûrnâme'si² olarak karşımıza çıkabilmektedir. İmâmzâde'nin Şir'atü'l-isslâm adındaki eserinin Türkçe tercümesi olan "Şir'a-i Manzûme", dijital katalogta "Terceme-i Şeri'atü'l-İslâm" adıyla ve 268 varak olarak kaydedilmiştir. ${ }^{23}$ Hem kaynak eserin adı hem de Türkçe tercümenin varak sayısı yanlış verilmiştir. Aynı eser, Kaliforniya Üniversitesi Los Angeles Kütüphanesi Türkçe Elyazmaları Özel Koleksiyonlar bölümünde ise "Ser'atül-Islam"24 adıyla kaydedilmiştir. Bu katalogta da kaynak eserin adı yanlış verilirken mütercimin adı ve tercüme eserin özgün adı ise hiç zikredilmemiştir. Princeton Üniversitesi Kütüphanesi'nin dijital kataloğunda yer alan Nesimî Mehmed'in Gülistân-ı Şemâil25 adlı eserinin müellifi "Âli-yi Şirin" olarak kaydedilmiştir. ${ }^{26}$ Yine aynı kütüphanede bulunan Mazlumî'nin Tercüme-i

17 Projelerin detayları için bk. MAYDAN, “Manuscripts - Digital Resources and Projects in Islamic Studies”, 11 Ocak 2021

18 Bu eserlerden birisi de Dâvûd-ı Halvetî́nin Gülşen-i Tevhid adlı eseridir. Bk. OAC, "Collection of Turkish manuscripts LSC.0896 - Gülsen-i Tevhid", 7 Ocak 2021; Abdülmecit İslamoğlu, Dâvûd-ı Halvetîve Gülşen-i Tevhîd ü Tahkîk'i (Inceleme-Metin), (Bolu: Bolu Araştırmaları Merkezi Yayınları, 2013)

19 Bu nüsha ile ilgili değerlendirme yazısı için bk. İ̧LERWEB, "İnebey Kütüphanesi'nde Gülzar-ı Manevi'nin Yeni Bir Nüshası: Sırru'I-Erkan”, 7 Ocak 2021; IŞLERWP, “İnebey Kütüphanesi'nde Gülzar-ı Manevi'nin Yeni Bir Nüshası: Sirru'l-Erkan", 8 Ocak 2021

20 YAZMALAR, “Kâfiye-nâme", 8 Ocak 2021

21 Bk. Yusuf Tepeli, Derviş Muhammed Yemini Fazilet-Name (Ankara: Türk Dil Kurumu Yayınları, 2000)

22 Bk. Niyâzî, Mansûr-nâme, nşr. Mustafa Tatcı (İstanbul: MEB Yayınları, 1994)

23 YAZMALAR, "Terceme-i Şeri'atü'l-İslâm”, 8 Ocak 2021 (Eserin varak sayısı 368 iken 268 olarak kaydedilmiştir. Muhtemelen "ץ" ve "Г" rakamlarının yazılışlarındaki benzerlik bu sehve sebebiyet vermiştir.)

24 OAC, "Collection of Turkish manuscripts LSC.0896 - Ser'atül-Islam", 7 Ocak 2021

25 Zülfikar Güngör, Türk Edebiyatında Türkçe Manzûm Hilye-i Nebeviler ve Nesimi Mehmed 'in Gülistan-ı Şemail ' $i$ (Ankara: Ankara Üniversitesi Sosyal Bilimler Enstitüsü, Doktora Tezi 2000)

26 PRINCETON, “Gülistan-ı Şemail”, 8 Ocak 2021 
Şemâil-i Şerîfe'sinin ${ }^{27}$ müellifi Âşık Paşa-yı Velî (1271-1332) olarak sisteme kaydedilmiştir. ${ }^{28}$ "Erzincanlı Terzi Baba"29 olarak da bilinen "Hayyât Vehbî" adını yazmalar.gov.tr'de "Hayatî Vehbî Terzi Baba Erzurûmî"30 olarak görebilmekteyiz. Cebeci İlçe Halk Kütüphanesi koleksiyonu A6 numarada kayıtlı bulunan Kenzu'l-Esrâr ${ }^{31}$ ise Abîrî'ye 32 (عبيرى) ait olmasına rağmen “Ubeydî (عبيدى) Feyz-Allâh Dede" adına kaydedilmiştir.

Bazı el yazma eserlerin üzerinde sehiv boyutlarını da aşan tahriflere rastlanmaktadır. Kataloğu hazırlayan kimseler bu bilgileri doğrudan dijital ortama aktarmaktadırlar. Ancak dikkatli bir muhteva incelemesiyle eserin doğru adına ulaşılabilmektedir. Sadık Yazar bir makalesinde ${ }^{33}$ mütercimi bilinmeyen manzûm Kudûrî tercümesinin bir nüshasını ${ }^{34}$ tanıtmıştır. Eser, gerçekte Devletoğlu Yusuf'un Vikâye tercümesidir. "Vikâye" adına dair nüshada hiçbir şeye rastlanmadığı gibi, araştırmacıyı yanıltabilecek neredeyse her şey vardır. Devletoğlu Yusuf'un tercümesinin ${ }^{35}$ çok önemli bilgiler ihtivâ eden ilk 165 beyti bu nüshada yer almamaktadır. Nüshanın mukaddimesine Kudûrî'nin mensûr metni konulmuştur. Ayrıca kapağa, fihriste ve nüshanın 1 b sayfasına da "Kudûrî" ismi yazılmıştır. Örnekleri çok olan bu tür yanlış, eksik ya da kasıtlı bilgilerin dikkate alınması akademik emeğin israf olmasının da önüne geçecektir.

\section{5. Âyet ve Hadisler İçin Dijital Kaynaklar}

Eski Türk Edebiyatı́nın en önemli kaynakları arasında şüphesiz ki âyet ve

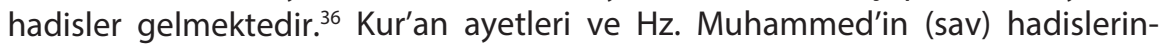
den beslenerek, Türk Edebiyatı sahasında birçok manzûm ve mensûr eser ortaya konmuştur. ${ }^{37}$ Âyet ve hadisler, sadece dini muhtevalı eserlerde olmayıp dîvânlarda da karşımıza çıkmaktadır. Bu âyet ve hadislerin kaynaklarının doğru bir şekilde tesbiti için başvurulabilecek adresler şunlardır:

27 Mehmet Akif Gözitok, Mazlumi'nin Tercüme-i Şemail-i Şerife'si (İstanbul: Kitabevi Yayınları, 2020)

28 PRINCETON, "Şerh üş-Şemail", 9 Ocak 2021

29 TEIS, “Erzincanlı Terzi Baba", 9 Ocak 2021

30 YAZMALAR, “Miftahü'l-Kenz - Demirbaş No: 27 Kilis 3189”, 10 Ocak 2021

31 KENZ, "Kenzu'I-Esrâr 06 Hk 6", 10 Ocak 2021

32 Abdülbaki ÇETiN, "XVII. Yüzyıl Mevlevî Şairlerinden 'Abîrî ve İki Eseri". A.Ü. Türkiyat Arastırmaları Enstitüsü Dergisi. S. 38. s. 97, 98; ABîRî, "ABÎRî, Feyzullâh, Feyzullâh el-Mevlevî, Feyzullâh Abîrî Dede”, 10 Ocak 2021

33 Bkz. Sadık Yazar, "Osmanlı Döneminde Fıkıh Sahasında Yapılmış Türkçe Tercümeler", Türkiye Araştırmaları Literatür Dergisi. 12/23 (2014), 63.

34 Manzûm Tercüme-i Kudûrî (İstanbul: Süleymaniye Kütüphanesi, Fatih Koleksiyonu, 2176)

35 Bu tercüme üzerine yapılan tez için bk. Bilal Aktan, Devletoğlu Yusuf'un Vikaye Tercümesi (Erzurum: Atatürk Üniversitesi Sosyal Bilimler Enstitüsü, Doktora Tezi 2002)

36 Ayet ve hadislerin edebiyatımıza kaynaklık etmesi konusunda bkz: Zülfikar Güngör, "Türk-İslâm Edebiyatının Kaynağı Olarak Kur'an-ı Kerîm", İslâmî Illimler Dergisi 1. Kur'an Sempozyumu (14-15 Ekim 2006/Çorum) (Çorum: İslâmî İlimler Dergisi Yayınları, 2007), s. 178-188; Zülfikar Güngör, "Türk-İslâm Edebiyatı́nın Kaynağı Olarak Hadisler", Hz. Muhammed ve Evrensel Mesajı Sempozyumu (20-22 Nisan 2007/Çorum), Çorum: İslâmi Illimler Dergisi Yayınları, 2007), s. 201-211.

37 Mehmet Yılmaz, Edebiyatımızda İslâmî Kaynaklı Sözler (İstanbul: Enderun Kitabevi, 1992), s. 3. Türk Edebiyatı'ndaki ayet ve hadis iktibasları örnekleri için ayrıca bk. Reyhan Keleş, Divan Şiirinde Ayet ve Hadis Iktibasları (İstanbul: Kitabevi Yayınları, 2016); Emel Nalçacıgil Çopur, 16. Yüzyıl Mesnevîlerinde Ayet ve Hadis Iktibasları (Konya: Uğur Tuna Yayınları, 2016) 
https://kuran.diyanet.gov.tr/mushaf (Diyanet Kuran-Kerim Meali)

https://acikkuran.com

https://mealler.org

https://www.kuranmeali.com

https://www.kurandaara.com

http://www.shamela.ws (el-Mektebetü'ş-Şâmile - Hadis Ansiklopedisi)

http://www.hadiskitaplari.com (Hadis Arama Motoru)

https://www.dorar.net (Hadis Arama Motoru)

http://hadithportal.com (Hadis Arama Motoru)

https://İslâmweb.net/ar/library/index.php (Hadis Arama Motoru)

İslâmî ilimlerin hemen hemen her alanından binlerce kitabı dijital ortamda bir araya getiren el-Mektebetü'ş-Şâmile ${ }^{38}$ de araştırmacılar için önemli bir kaynaktır. Bu program sayesinde bir hadisin tahkikli ve tahriçli matbu kaynaklarına ulaşmak saniyeler içinde mümkün olabilmektedir. ${ }^{39}$

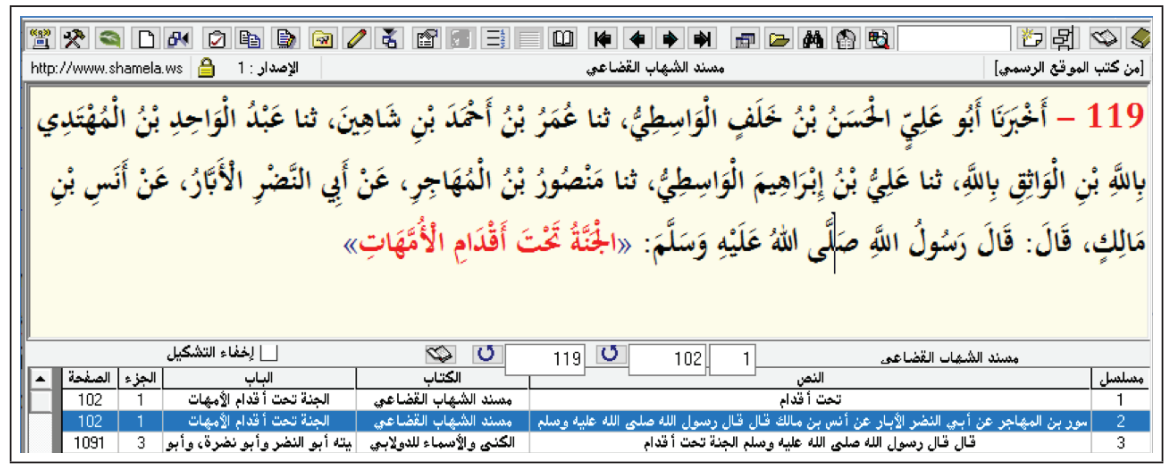

Resim 1: el-Mektebetü'ş-Şâmile programının kişisel bilgisayarımızdaki ekran görüntüsü.

\section{Dijital Sözlükler}

Matbu sözlüklerin dijital metinlerine ve görsellerine saniyeler içerisinde artık ulaşabilmekteyiz. "Behişt osmanlıca" ya da "بهشت Osmanlıca" şeklinde genel arama motorlarında arama yapıldığında, bir asır önce Arap harfleriyle basılmış "Kamûs-ı Türkî", "Lügat-i Naci”, "Lügat-i Remzi", "Lehçe-i Osmânî", "Lugat-i Ebüzziyâ" gibi birçok sözlüğün matbu görsellerine rahatlıkla ulaşılabilmektedir. Bu durum araştırmacılar için önemli bir zaman tasarrufu sağlamaktadır.

38 Necmeddin GÜNEY, "Bilgisayar Ortamındaki İslâmî îlimler Konulu Arapça Program ve CD’ler Üzerine”, Marife, 5/2 (2005), 174.

39 el-Mektebetü'ş-Şâmile'nin kurulum ve kullanımıyla ilgili bk. SHAMELA, "Er-Re'isiyye”, 11 Ocak 2021; ISNAD, "Şamile Eğitimi", 11 Ocak 2021; iD, "ilahiyatçının İnternet Kılavuzu”, 11 Ocak 2021 
Online sözlüklerin dışında bağlamlı sözlük çalışmaları da vardır. Temelleri 2007 yılında atılan "Tarih ve Edebiyat Metinleri Bağlamlı Dizin ve İşlevsel Sözlüğü"40 (Tebdiz) projesi, edebiyat alanında çalışanlar için çok önemli bir hazinedir. Edebî metinlerin bağlamlı dizin ve işlevsel sözlüğünü oluşturmayı amaçlayan Tebdiz, aynı zamanda bir metin bankası özelliği taşımaktadır. 7 Kasım 2018 tarihi itibariyle sisteme yüklenen 670 eser $^{41}$ içerisinden aranan kelimelerin şahitlerine ulaşılabilmektedir. Proje, Prof. Dr. İsmail Hakkı Aksoyak ve öğrencilerinin çok büyük emekleriyle devam ettirilmektedir. "Tebdiz projesi ile; Türk dili ile yazılmış olan eserlerdeki sözcüklerin, hangi sözcüklerle bir araya getirildiği, hangi anlamlarda ve bağlamlarda kullanıldığı ortaya konulabilmektedir. Ayrıca, edebî eserlerdeki folklorik unsurlar tespit edilebilmekte, dilin tarihsel süreçte geçirdiği değişim takip edilebilmektedir."42 Bu proje kapsamında "Hızlı Transkripsiyon", "Metin Tamiri", "Aruz Bulma" ve "Osmanlıca Yazma" uygulamaları yapım aşamasındadır. ${ }^{43}$

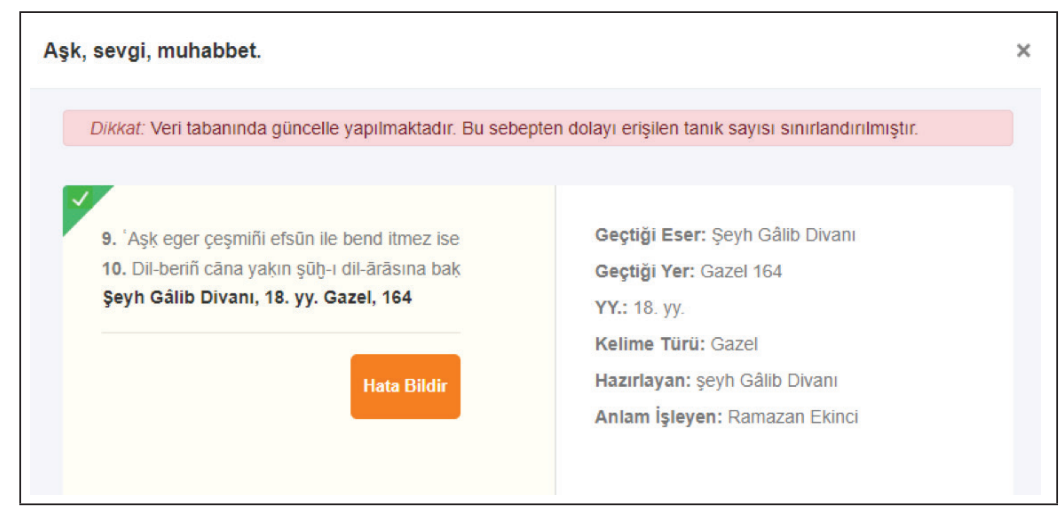

Resim 2: Tebdiz.com'da “Aşk" kelimesi taraması ekran görüntüsü.

Metin çalışmalarının sözlükleri oluşturulurken bazı yanlış anlamlandırmalar olabilmektedir. Tebdiz'de de yer alan benzer yazılışlı kelimelerin ${ }^{44}$ bazılarına hatalı anlam girişleri yapılmıştır. Aşağıdaki örnekte "yara" 45 anlamına gelen "baş" kelimesi, "bir şeyin başladığı yer, baş tarafı" şeklinde anlamlandırılmıştır. Bin yıllık geçmişi tarayan bu önemli sözlük, bu tür yanlışların fark edilip düzeltilebilmesi için "Hata bildir" seçeneğiyle kullanıcıların katkısını da beklemektedir.

40 Fatih Özer, "Tarih ve Edebiyat Metinleri Bağlamlı Dizin ve İşlevsel Sözlüğü Sistemi (TEBDiZ)". Bilig - Türk Dünyası Sosyal Bilimler Dergisi, 86 (2018), 219-221.

41 Bugün itibariyle taranan eserlerin sayısı sistem üzerinde 1272 olarak görünmektedir. Bk. TEBDiZ, “Taranan Eeserler", 15 Şubat 2021

42 TEBDiZ,"Hakkımızda”, 15 Şubat 2021

43 TEBDiZ, "Klavuz", 15 Şubat 2021

44 Benzer yazılışıı kelimeler için bk. Mehtap Erdoğan, Osmanlı Türkçesinde Benzer Yazılışlı Kelimeler Sözlüğü (Ankara: Grafiker Yayınları, 2009); Selami Ece, Klasik Türk Edebiyatı Araştırma Yöntemleri l-II (Erzurum: Eser Basım Yayınları, 2015)

45 SÖZLUK, “Baş Kelimesi - Tarama Sözlüğü" 15 Şubat 2021 
Bir şeyin başladığı yer, baş tarafı.

Dikkat: Veri tabanında güncelle yapılmaktadır. Bu sebepten dolayı erişilen tanık sayısı sınırlandırıımıştır.

3. Bagrumuñ başlarını arasa dil-dâr ne var

4. Bilür ol kim kişi itdüklerini bulsa gerek

Azmî-zâde Hâletî Dîvânı, 17. yy. Gazel, 425

Hata Bildir
Geçtiği Eser: Azmî-zâde Hâletî Dîvânı

Geçtiği Yer: Gazel 425

YY.: 17. yy.

Kelime Türü: Gazel

Hazırlayan: Kaya, Bayram Ali (2003). The

Resim 3: Tebdiz.com'da “baş” kelimesi taraması ekran görüntüsü.

Eski metinlerin anlaşılmasında kullanılan temel sözlüklerden olan "Tarama Sözlüğü" ve "Derleme Sözlüğü" de dijital ortama aktarılmıştır. Sozluk.gov.tr adresinden yayımlanan sözlükte matbu yayının taranmış görsellerine de ulaşılabilmektedir:

sevü, (sevi)

Sevgi, aşk, muhabbet.

Sevüñdür سوكدر bil seni senden rradan

Ne sever isen ol yanaya yeden (Yunus. XIII-XIV. 5)

Gönül, canım, usum, bilüm senin ile karar eder

Can kanadx sevi سوى gerek uçuban dosta gitmeğe

(Yunus. XIII-XIV. 61)

Ben gelmedim da'vi içün benim işim sevi içün

Gönüiller dost evi içün gönüller yapmağa geldim

(Yunus. XIII - XIV. 236)

Resim 4: Sozluk.gov.tr'de “Sevü" kelimesi taraması. Kaynak: Sozluk.gov.tr

Türkçe kelimeler için taranabilecek dijital sözlükler şunlardır:

http://www.lugatim.com

https://www.sozluk.gov.tr

http://www.tebdiz.com

http://tr.wiktionary.org

https://www.etimolojiturkce.com

http://www.kamusiturki.net

http://www.belgelisozluk.com

https://www.trceviri.com 
https://memalik.cagdassozluk.com

https://ingilizce.cagdassozluk.com

https://muntehab.cagdassozluk.com

https://www.ebuzziya.com

https://kamusiosmani.net

https://remzi.cagdassozluk.com

http://www.ingilizceosmanlica.com

http://www.osmanlicakitaplar.com

http://www.ebuzziya.com

http://www.lugatinaci.com

http://www.enacademic.com

http://www.luggat.com

http://www.osmanlicaturkce.com

http://www.osmanice.com

https://www.turkcenindirilisi.com

https://altaica.ru/v-turks.php

https://altaica.ru/LIBRARY/turks/Mahmud_turkish_index.pdf

https://www.turkbitig.com/eskiturkcesozluk.html

https://turuz.com/book/title/Osmanli+Turkcesi+Qilavuzu-1-2-Hayati+Develi https://books.google.com.tr/books?id=bAeXDwAAQBAJ

Türkiye'de dijital erişime açılan önemli sözlüklerden birisi de kamus.yek.gov. tr'dir. Arapça-Osmanlıca sözlüklerden el-Okyânûsu'l-Basît ile Vankulu Lügati, bu site üzerinden taranabilmektedir. Ekran klavyesi seçeneği de bulunan sitede kelimelerin hem Arap harfli hem de Latin harfli yazılışları bulunmaktadır:

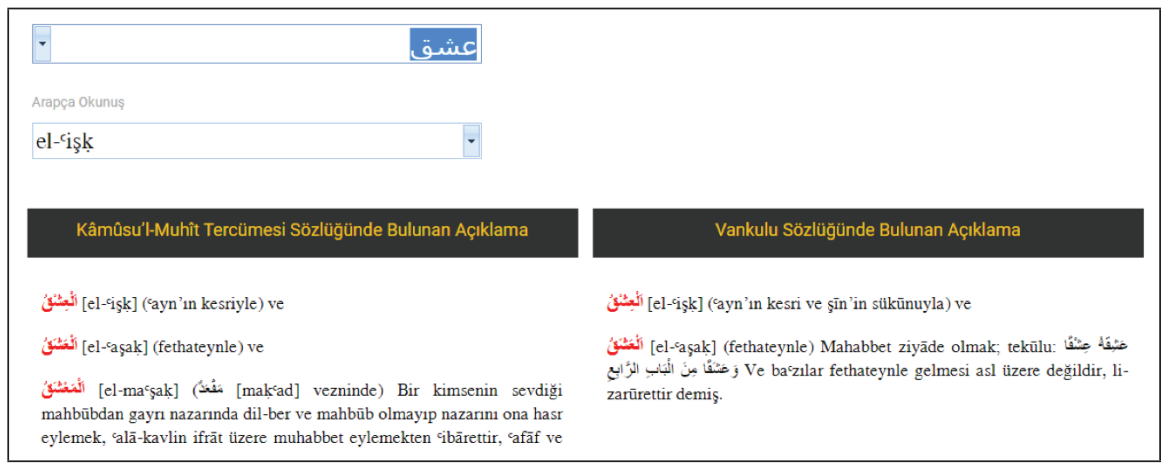

Resim 5: Kamus.yek.gov.tr’de “ışk” kelimesi taraması ekran görüntüsü. 
Arapça kelimeler için taranabilecek diğer dijital sözlükler şunlardır:

https://www.almaany.com/tr/dict/ar-tr/

https://www.tevakku.com

https://www.maajim.com

http://46.101.185.202/search

http://arabiclexicon.hawramani.com

http://ar.wiktionary.org

https://books.google.com.tr/books?id=_n5iDwAAQBAJ

https://en.wiktionary.org/wiki/\%D8\%B5\%D9\%81\%D8\%AD\%D8\%A9_\%D8\%

B1\%D8\%A6\%D9\%8A\%D8\%B3\%D9\%8A\%D8\%A9

\section{Microsoft Word ile Metin Transkripsiyonu ve Metin İçi Aramalar}

Bir alfabede yer alan harflerin bazı özel işaretler ilâvesiyle başka bir alfabenin karakterlerine çevrilmesine çeviri yazı ya da transkripsiyon denilmektedir. Farklı disiplinlerde kullanılmakla birlikte, Türkiye'de daha çok Arap harfli metinlerin Latin harflerine çevrilmesi amacıyla bu sisteme başvurulmaktadır. Tarihî ve edebî metin neşirlerinde transkripsiyon sistemi kullanılmaktadır. Türkiye'de transkripsiyon konusunda genel hatlarıyla birliğin sağlandığını söyleyebiliriz. Bu sistemin teorik arka planı Diyanet Ansiklopedisi'nin "transkripsiyon" maddesinde ele alınmıştır. ${ }^{46}$ Biz burada transkripsiyonu teknik ve pratik açıdan değerlendireceğiz.

Ofis uygulamaları akademik çalışmanın vazgeçilmez araçlarıdır. Bu araçların verimli kullanılabilmesi için mutlaka bir kursa gidilmeli ya da basılı ve dijital kaynaklardan istifade edilmelidir. Eski Türk Edebiyatı metin çalışmalarında kullandığımız ofis araçlarından bir tanesi de Microsoft Word'dür. Transkripsiyon konusunda Türkiye'de Oktay New Transkripsiyon, Times Turkish Transcription fontları Microsoft Word programı içerisinde uzun yıllar kullanılmıştır ve halen de kullanılmaya devam etmektedir. Bu iki fontun artık miadını doldurduğunu ifade eden İsa Sarı, Transkripsiyon Klavyesi'ni online olarak hizmete sunmuştur. ${ }^{47}$ Bu çalışma birçok diyakritiğe (aksan) imkân tanımakla birlikte hacimli metinlerin transkripsiyonu için pratik görünmemektedir. Tebdiz projesinde kullanılan Gentium Font'da ${ }^{48}$ ise peltek s'ler (ث), "s $\hat{s}$ " karakteri ile karşılanırken; Arapça ve Farsça kelimelerin asli uzunluklarından olan "uzun i"ler ise "iّ" karakteri ile karşılanmıştır.

Transkripsiyon konusunda font ve pratik kısayol ihtiyaçları üzerinde 2002 yılından beri çalışmalar yapmaktayız. 2004 yılında Oktay New Transkripsiyon fontu ile yaptığımız Osmanlıca Transkripsiyon Programı́nı, 2017 yılında güncel-

46 İsmail Durmuş, "Transkripsiyon", Türkiye Diyanet Vakfı İslâm Ansiklopedisi, 11 Ocak 2021

47 SARI, "Transkripsiyon", 11 Ocak 2021. İsa Sarı́nın bir diğer önemli çalışması da "geliştirilmiş osmanlıca/arapça klavye"dir. Bk. SARI, "Geliştirilmiş Osmanlıca/Arapça Klavye", 11 Ocak 2021. Android ve IOS sistemleri için üretilen diğer önemli bir uygulama da "oklavye"dir. OKlavye için bk. OKLAVYE, "OKlavye İle Osmanlıca Yazmaya Başla", 11 Ocak 2021

48 DAFONT, “Gentium”, 11 Ocak 2021 
leyerek tek bir "Word" belgesi haline getirdik. Bu Word belgesinin içinde "Times New Roman" fontunu kullandık. Bu font üzerinde sadece " $\hat{s}$ " ve " $i$ " karakterleri üzerinde değişiklik yapılarak, altı çizgili "s" ve üstü tek nokta ve çizgili "i" karakteri elde edilmiştir. Transkripsiyon alfabesindeki harfler en uygun kısayollara atanmış ve modifiye edilen font, kısayolların bulunduğu Word belgesinin içine yerleştirilmiştir. Düşük performanslı bilgisayarlarda, içinde font barındıran bu belgeyle çalışmak zaman kaybına yol açabilmektedir. Bu yüzden kaydetme sıklığı word seçenekleri >> Kaydet >> kaydetme sıklığı yolunu takip ederek değiştirilebilir. 2017 yılında sitemizde yayımladığımız Osmanlıca Transkripsiyon Programı 3.0 (OTP 3.0), araştırmacıların hizmetine ücretsiz olarak sunulmuştur. ${ }^{49}$

Osmanlıca Transkripsiyon Programı 3.0'a atanan kısayollarda daha çok Ctrl ve Shıft( $\uparrow)$ tuşları kullanılmıştır. Ctrl ve Shıft tuşlarının en solda olduğu bilgisayarlar, transkripsiyon alfabesi ile yazarken kolaylık sağlamaktadır. Sol köşeye "Fn" (Fonksiyon) tuşunun yerleştirildiği klavyelerle çalışmak zor olabilmektedir. Fn ve Ctrl tuşlarının görevleri bazı bilgisayarlarda bulunan swap (takas) özelliği ile değiştirilebilmektedir.

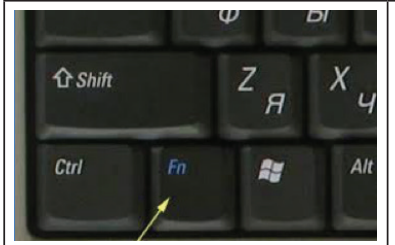

Resim 6: Ctrl tuşu en solda olan klavye. Kaynak: vism.ru (OTP 3.0 Kaynak: vism.ru için önerilen) olan klavye.

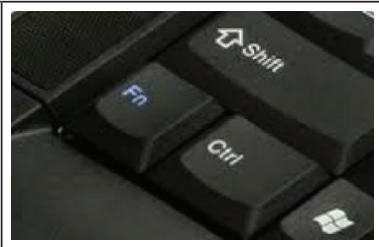

Resim 7: Fn tuşu en solda Kaynak

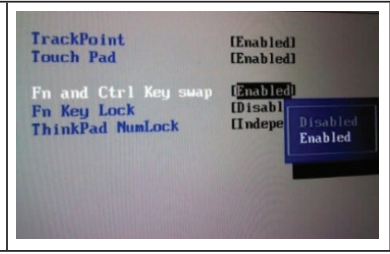

Resim 8: Fn ve Ctrl tuşlarını BIOS'tan swap Kaynak: jdhodges.com

Osmanlıca Transkripsiyon Programı 3.0'da kullanılan kısayollar aşağıdaki görseldeki gibidir. Belgeye atanan kısayollar değiştirilebilir. Harfi, metinden seçerek şu yol takip edilmelidir: Ekle >> Simge >> Tüm Simgeler $>>$ Kısayol Tuşu (Ctrl, Alt ya da Shift'e basarak atama yapılır.)

49 iŞLERWEB, "Osmanlıca Transkripsiyon Programı”, 11 Ocak 2021; IŞLERWP, “Osmanlıca Transkripsiyon Programı 3.1", 11 Ocak 2021; ACADEMIA, “Osmanlıca Transkripsiyon Programı 3.1”, 11 Ocak 2021 


\begin{tabular}{|c|c|c|c|c|c|}
\hline \multirow[t]{2}{*}{ c } & : Ctrl 6 ve Ctr11 (Ayn için) & $\mathbf{s}$ & : Ctrl S & d & Alt D \\
\hline & \multirow{2}{*}{ : Ctr1 9 ve Ctr12 (Hemze için) } & $\mathbf{S}$ & : Ctrl Shifts & D & Alt Shift D \\
\hline \multirow{2}{*}{ - } & & $\mathbf{s}$ & $\therefore$ AltS & $z$ & $\mathrm{Ctr} 1 \mathrm{Z}$ \\
\hline & 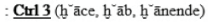 & $\underline{\mathbf{S}}$ & : Alt ShiftS & $\mathbf{Z}$ & Ctr1 Shift Z \\
\hline$\overline{\mathbf{a}}$ & : Ctrl A & h & : Ctrl H & $\underline{z}$ & AltZ \\
\hline$\overline{\mathbf{A}}$ & $=$ Ctrl Shift A & $\mathbf{H}$ & : Ctrl Shift H & $\underline{\mathbf{Z}}$ & Alt Shift Z \\
\hline ě & : Ctrl e (Imâleli e: dilêrem) & b & Alt $\mathrm{H}$ & d & Alt X (Hud̄ā, Bürāder) \\
\hline$\overline{\mathbf{i}}$ & $=\operatorname{Ctrl} \mathrm{I}$ & $\mathrm{H}$ & :Alt Shift H & D & Alt Shift X \\
\hline $\mathbf{I}$ & : Ctr1 Shift I & $\mathbf{k}$ & $: \mathrm{Ctr1} \mathrm{K}$ & ñ & $\mathrm{Ctr} 1 \mathrm{~N}$ \\
\hline$\overline{\mathbf{u}}$ & : Ctrl U & $\mathbf{K}$ & Ctrl Shift K & $\tilde{\mathbf{N}}$ & Ctrl Shift N \\
\hline $\mathbf{U}$ & : Ctrl Shift U & $\dot{\mathbf{z}}$ & : Ctrl D & $\mathbf{t}$ & $\mathrm{Ctrl} 1 \mathrm{~T}$ \\
\hline & necatiisler.com & $\dot{\mathbf{Z}}$ & : Ctrl Shift D & $\mathbf{T}$ & Ctrl Shift T \\
\hline
\end{tabular}

Resim 9: OTP 3.0'da kısayol tuşları. Kaynak: necatiisler.com

Osmanlıca Transkripsiyon Programı 3.0 ile yazılan metinler MacOS, Windows, IOS ve Abdroid işletim sistemlerinde bozulmaya uğramadan kullanılabilmektedir.

Metin çalışmalarında Word programını kullanırken 1000 sayfayı aşan büyük dosyalar oluşabilmektedir. Bu tür dosyalarla çalışabilmek için bilgisayarın iyi bir işlemci, RAM ve SSD hard diske sahip olması gerekmektedir. Özellikle hacimli ve çok sayıda dosya ile çalışırken bu performans ihtiyacı ön plana çıkmaktadır. Metin içinde arama işleminde de bu ihtiyaç kendini ciddi anlamda hissettirmektedir. Word 2010 ile birlikte metin içerisindeki arama aracı daha da işlevsel hale gelmiştir. Aradığımız kelime ya da kelime grubunun metinde kaç defa ve nerelerde geçtiğinin özetini "Ctrl F" tuşu ile açılan "Gezinti" bölümünde görebilmekteyiz.

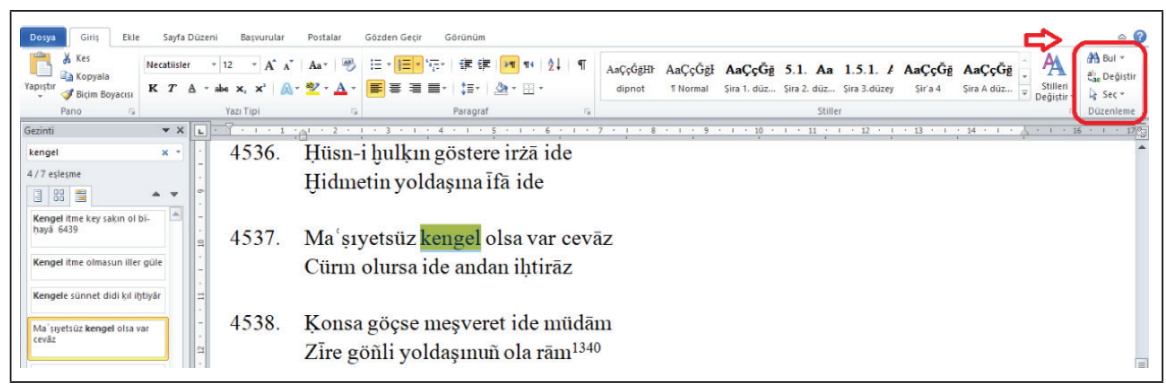

Resim 10: Kelimenin metindeki tekrar sayısını Ctrl F komutuyla "Gezinti" aracında görüntüleme..$^{50}$

50 Bu bölümde kullanılan görseller doktora çalışmamızın ekran görüntülerinden oluşmaktadır. Bk. Necati İşler, Muhammed b. Ibrahim'in Manzûm Şir'atü'Iİ̀sâm Tercümesi (Şir'a-i Manzûme), (Ankara: Ankara Üniversitesi Sosyal Bilimler Enstitüsü, Doktora Tezi 2021) 
Kelimeleri toplu halde değiştirmek istiyorsak "Giriş" menüsü içerisinde yer alan "Bul ve Değiştir" görevini seçebiliriz. Toplu halde yapılan değiştirmeler (Tümünü Değiştir) her zaman risk barındırır. Bu yüzden bulunan metni değiştirirken tek tek onay verilmelidir. Bu durum, zaman kaybına yol açsa da en güvenli yoldur:

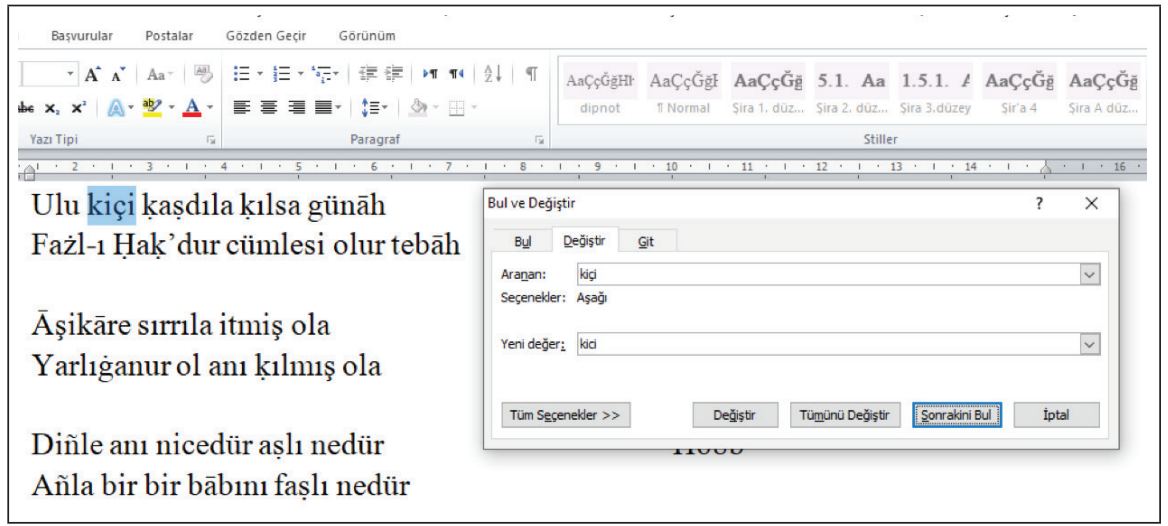

Resim 11: “Bul ve Değiştir” ile kelime değiştirme.

Özel karakterlerle (wildcard/joker karakter) ${ }^{51}$ yapacağımız aramalar bizleri daha özel sonuçlara ulaştıracaktır. "Bul ve Değiştir" menüsündeki "Tüm Seçeneklerden" joker karakterlere ulaşabiliriz. Örneğin soru işaretini joker karakter olarak kullanacaksak öncelikle "Joker karakter kullan" seçeneğini işaretlemeliyiz. "b?n" şeklinde bir arama ile "b" ile başlayıp " $n$ " ile biten kelimelere ulaşabiliriz. Böyle bir aramada başta ve sonda boşluk bırakılmaz ise "benim", "leben”, "dürbin" gibi kelimeler de bulunacaktır.

51 HB, “Word 2016'da Arama Yaparken Joker Karakterler Nasıl Kullanılır", 2 Mart 2021; UK, "Microsoft word'de joker karakter kullanımı", 2 Mart 2021 


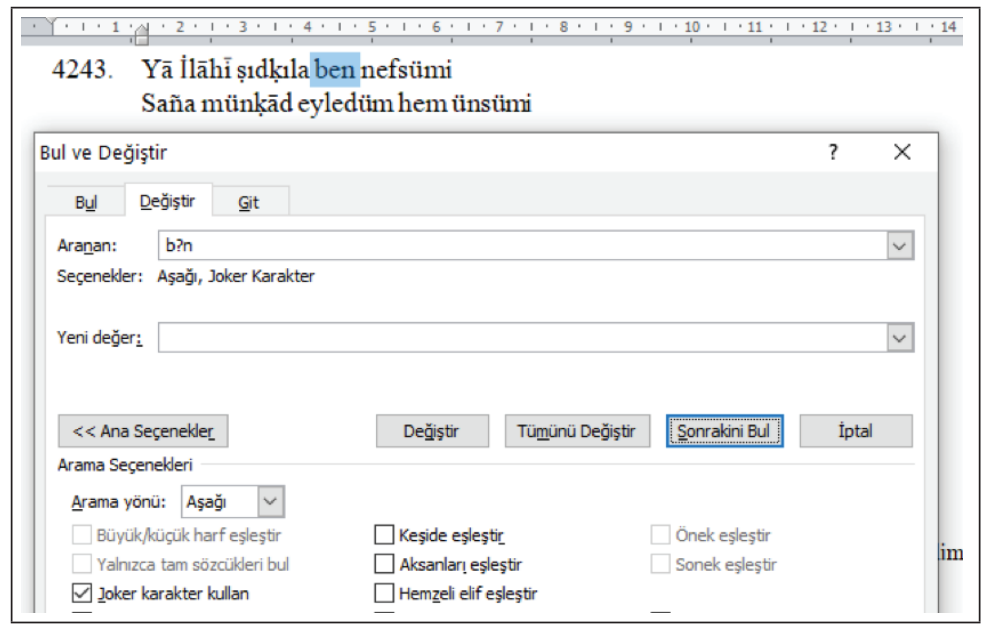

Resim 12: Joker karakterlerle arama yapma.

Dipnotları toplu halde silmek için "Bul ve Değiştir" aracını kullanabiliriz. " $\wedge$ " karakterleriyle yapacağımız aramada dipnotlara ulaşabiliriz. Şapka karakteri için klavye kullanabileceğimiz gibi Bul ve Değiştir >> Ana Seçenekler >> Özel yolunu takip ederek dipnot işaretini $(\wedge f)$ aranan değer olarak belirleyebiliriz. "Yeni Değer"i boş bırakıp "Tümünü Değiştir"e tıkladığımızda metindeki bütün dipnotlar silinecektir. "Joker karakter kullan" seçeneği işaretli iken "Ana seçenekler"den ulaşılan "özel" karakterler daha sınırlı çıkmaktadır. Bu yüzden bu işareti kaldırarak daha çok seçeneğe ulaşmış oluruz.

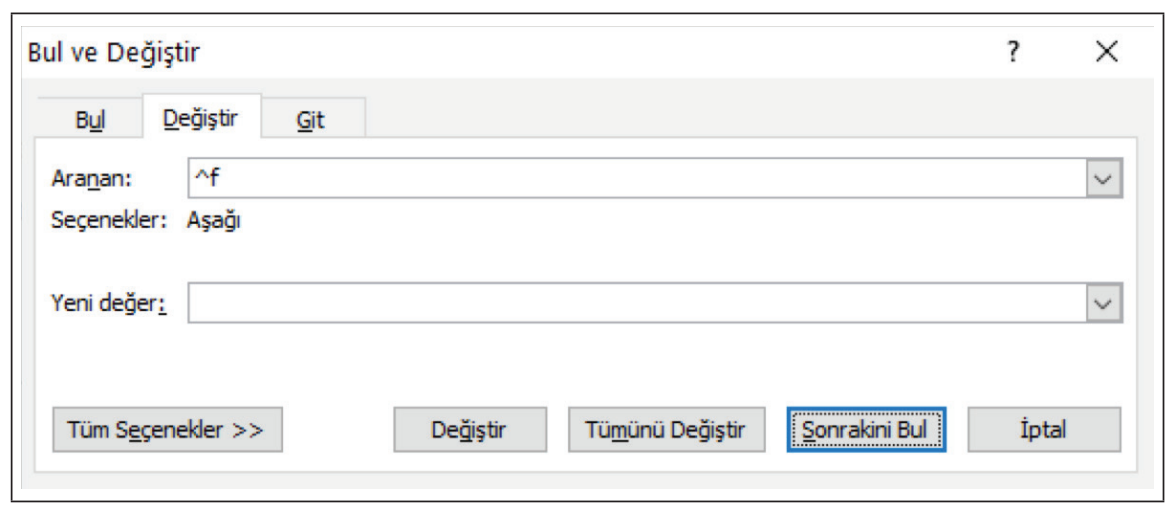

Resim 13: Dipnotların toplu halde silinmesi. 
Satır başındaki bir kelimeyi bulmak için joker karakteri kullan seçeneğini iptal ederek "Aranan" bölümüne Ana Seçenekler >> Özel >> Parağraf İşareti yoluyla "^p" karakterleri yazılmalıdır. Bu karakterler "şapka işareti" ve "p harfi" tuşlanarak da eklenebilir. Eğer satır sonundaki kelimeler bulunmak isteniyorsa "^p" karakterleri "Aranan" bölümünde kelimenin sonuna yazmak gerekmektedir. "^ptüñ" şeklinde bir arama ile satır sonlarındaki "žilletüñ" "raġbetüñ", "meyyitüñ", "ḥürmetüñn" gibi kelimeler bulunur.

\begin{tabular}{|c|c|c|c|c|c|c|c|c|c|}
\hline 5202. & \multicolumn{4}{|c|}{$\begin{array}{l}\text { Yā İlāhī sen münezzeh Tangrı'sin } \\
\text { Raḥmet itdüñ her ki bildi Tangrı'sın }\end{array}$} & 5208. & \multicolumn{4}{|c|}{$\begin{array}{l}\text { Kapuña geldüm umaram rahmetüñ } \\
\text { Tevbe itdüm cürmüme ḳll re fetüñ }\end{array}$} \\
\hline \multicolumn{5}{|c|}{ Bul ve Değiştir } & \multicolumn{3}{|c|}{ Bul ve Değiştir } & & \\
\hline \multirow{3}{*}{$\begin{array}{l}\text { Bull } \\
\text { Aranan: }\end{array}$} & Değisțtir & Git & & & \multirow{3}{*}{$\begin{array}{l}\quad \text { Bul } \\
\text { Arañan: } \\
\text { Seçenekler: } \\
\text { Yeni değer: }\end{array}$} & Değiștir & Git & & \\
\hline & \multicolumn{4}{|c|}{ ^pYã ilähī } & & \multicolumn{2}{|l|}{ tuัก๊^p } & & \\
\hline & & & & & & & & & \\
\hline \multicolumn{3}{|c|}{$\ll<$ Ana Seçenekler } & Okuma Vurgusu - & Bulunaca & \multicolumn{2}{|c|}{$\ll<$ Ana Seçenekler } & & Değiştir & Tümün \\
\hline
\end{tabular}

Resim 14-15: Satır başı ve sonlarındaki kelimelerin bulunması.

Transkripsiyonlu metinlerle çalışırken aradığımız kelime ya da kelime grubunu ana metinden kopyalayarak almalıyız. Çünkü "ñ", "ḳ", "hn” gibi karakterleri klavye kısayolları ile "Bul ve Değiştir" aracında yazma imkânı yoktur. Ctrl F tuşları ile belgenin solunda açılan "Gezinti" bölümünde de aynı şekilde kısayol tuşları kullanılamamaktadır. Bu yüzden kopyala/yapıştır yöntemi burası için de geçerlidir.

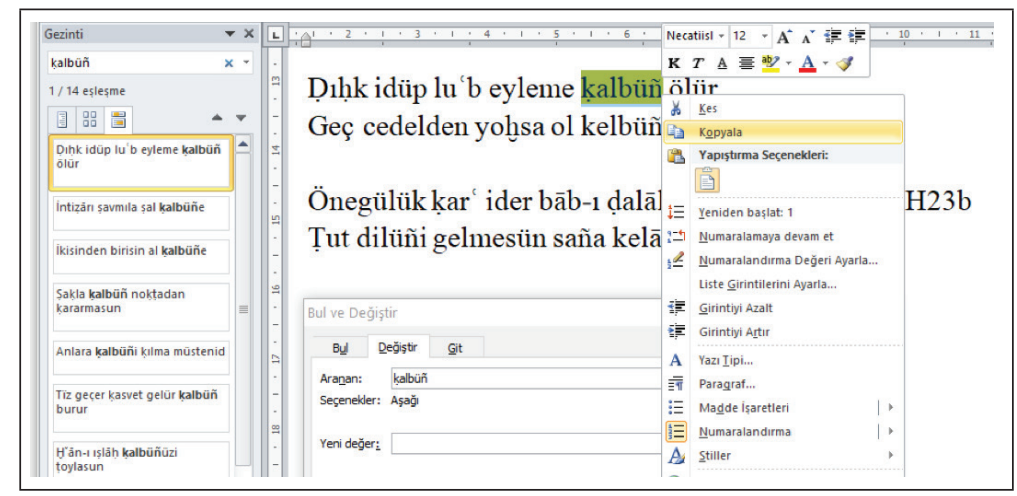

Resim 16: Ana metinden “Bul ve Değiştir"e metin kopyalama. 
Hazırladığımız word belgemizi pdf olarak kayıt seçeneği word 2010'dan beri bulunmaktadır. Belgemizi, Dosya >> Farklı Kaydet >> Kayıt Türü(pdf) yolunu kullanarak pdf olarak kaydedebiliriz. Word kullanımı ile ilgili verdiğimiz bu ipuçları ile iktifa etmek istiyoruz.

\section{Sonuç}

Bu makalemizde ele aldığımız dijital kaynaklar, internet vasıtasıyla bize sunulan içeriklerden oluşmaktadır. Veri tabanları, ansiklopediler, kitaplar, süreli yayınlar, makaleler, tezler, elektronik kitaplar akademik çalışmada öncelikli dijital kaynaklardandır. Eski Türk Edebiyatı alanında yayın ya da tez çalışması yapmak isteyen bir araştırmacı için literatür taraması, el yazma eserlere erişim, dijital sözlüklere erişim, metin transkripsiyonu gibi hususlar önem arz etmektedir.

Bilimsel çalışmalarda ilk ve en önemli adım literatür taramasıdır. Türk Edebiyatı İsimler Sözlügü Projesi, Kültür Bakanlığı'nın Metin Bankası ve E-kitap projeleri, literatür taramasında kullanacağımız önemli projelerdendir. Bu projelerin dışında kapsamlı bir taramaya imkân veren birçok veritabanı mevcuttur. Literatür çalışmasından sonra belirlenen konu ve taslağının web ortamında duyurulması, aynı çalışmanın farklı bir araştırmacı tarafından yapılmasına engel olarak emek israfının önüne geçecektir. Web siteleri ve sosyal medya hesapları çalışma konumuzu duyurmak için önemli araçlardandır.

Kütüphanelerde ve dijital platformlarda binlerce el yazma eser bulunmaktadır. Yazma eserler için Türkiye'deki en büyük dijital katalog yazmalar.gov.tr'dir. Dilekçe yazarak buradaki el yazma eserlerin dijital kopyalarından faydalanmak mümkündür. Yurt dışındaki el yazma eserleri ise e-posta, "ask a librarian" (kütüphaneciye sor) ve sistem üyeliği gibi farklı yöntemlerle talep edilebilmektedir. Dijital kataloglarda tarama yaparken eserin adı, müellifi, dili, varak sayısı gibi bilgilerin yanlış olma ihtimali her zaman dikkate alınmalıdır.

Kur'an-ו Kerim mealleri, Hadis ansiklopedileri ve dijital sözlükler de Eski Türk Edebiyatı araştırmalarında ihtiyaç duyulan önemli dijital kaynaklardandır. Tarama ve Derleme sözlüğü dışında pek çok sözlüğe de ev sahipliği yapan sozluk.gov.tr, bin yıllık geçmişi tarayan bağlamlı sözlük Tebdiz ve kamus.yek.gov.tr önemli dijital sözlüklerimizdendir.

Ofis uygulamaları akademik çalışmanın vazgeçilmez araçlarıdır. Bu araçların verimli kullanılabilmesi için mutlaka basılı ve dijital kaynaklardan istifade edilmelidir. Eski Türk Edebiyatı metin transkripsiyonu çalışmalarında kullandığımız ofis araçlarından bir tanesi olan Microsoft Word'dür. Bu uygulamanın bütün işlevleriyle etkin kullanılması, akademik çalışmanın verimini artıran önemli faktörlerdendir. Türkiye'de transkripsiyon konusunda genel hatlarıyla birliğin sağlandığını söyleyebiliriz. Makalemizde detaylarını verdiğimiz Osmanlıca Transkripsiyon Programı 3.0 ile kısayollar ve özel font, bir word belgesinde toplanmıştır. Bu belge, metin transkripsiyonu yapanlar için kullanışlı bir araca dönüştürülmüştür. 


\section{Kaynakça}

ABÎRÎ, “ABÎRî, Feyzullâh, Feyzullâh el-Mevlevî, Feyzullâh Abîrî Dede”. 10 Ocak 2021. http:// teis.yesevi.edu.tr/madde-detay/abiri-feyzullah-feyzullah-elmevlevi

ACADEMIA, Academia.edu Necati İşler Sayfası. "Osmanlıca Transkripsiyon Programı 3.1". Erişim 11 Ocak 2021. https://www.academia.edu/36242092/osmanlica_transkripsiyon_programi_3_1_docx

ACADEMIA, Academia.edu Necati Işsler Sayfası. "Proje ve Tezler". Erişim 7 Ocak 2021. https://www.academia.edu/295.42243/Proje_ve_tezler_Fethi_Ferah_name_Ferahname_Fethiyyat_fethiyat_docx

Ağaoğlu, Bülent. “Kamuya Açık Yerli Dijital Kaynaklar: Kitap, Dergi, Makale, Tez, Yazma, Rapor, Haber, Tutanak, Illan, Köşe Yazısı, Mevzuat, Açık Arşiv". Türk Kütüphaneciliği 27 (2013), 385-397.

AK, Akademik Kaynak. "Literatür Taraması Nedir ve Nasıl Yapılır ?". Erişim 2 Aralık 2020. https://www.akademikkaynak.com/literatur-taramasi-nedir-ve-nasil-yapilir.html

Aktan, Bilal. Devletoğlu Yusuf'un Vikaye Tercümesi. Erzurum: Atatürk Üniversitesi Sosyal Bilimler Enstitüsü, Doktora Tezi 2002.

Atila, Mustafa. "Klâsik Türk Edebiyatı Sahasının E-Kaynakları". VIII. Klâsik Türk Edebiyatı Sempozyumu-Alî Emîrî Hatırasına-2012. Diyarbakır: Diyarbakır Valiliği Kültür Sanat Yayınları, 2014, 29-44

Birol, Nurettin. “Halil Rıfat Paşa”. Cumhuriyet Üniversitesi Sosyal Bilimler Dergisi 27/2 (2003), 267-288.

Büyükaslan, Ali. "Edebiyat Araştırmalarında İnternet". Selçuk Üniversitesi Sosyal Bilimler Enstitüsü Dergisi 8 (2002), 67-86.

Çeçen, Mehmet Korkut. "Eski Türk Edebiyatı Araştırmalarında Bilgisayar Teknolojisinin Kullanımına Dair Bazı Düşünceler". Turkish Studies, 9/9 (2014), 351-366.

Çetin, Abdülbaki. "XVII. Yüzyıl Mevlevî Şairlerinden 'Abîrî ve İki Eseri”. A.Ü. Türkiyat Arastırmaları Enstitüsü Dergisi. S.38. s. 95-110.

Çopur, Emel Nalçacıgil. 16. Yüzyıl Mesnevîlerinde Âyet ve Hadis İktibasları. Konya: Uğur Tuna Yayınları, 2016.

DAFONT, Dafont. “Gentium”. Erişim 11 Ocak 2021. https://www.dafont.com/gentium.font

Durmuş, İsmail. "Transkripsiyon”. Türkiye Diyanet Vakfı İslâm Ansiklopedisi. 11 Ocak 2021. https://islamansiklopedisi.org.tr/transkripsiyon

Ece, Selami. Klasik Türk Edebiyatı Araştırma Yöntemleri I-II. Erzurum: Eser Basım Yayınları, 2015.

Erdoğan, Mehtap, Osmanlı Türkçesinde Benzer Yazılışlı Kelimeler Sözlüğü. Ankara: Grafiker Yayınları, 2009.

Gözitok, Mehmet Akif. Mazlumi'nin Tercüme-i Şemail-i Şerife'si. İstanbul: Kitabevi Yayınları, 2020.

Güney, Necmeddin. "Bilgisayar Ortamındaki İslâmî illimler Konulu Arapça Program ve CD'ler Üzerine". Marife 5/2 (2005), 153-185.

Güngör, Zülfikar. "Türk-İslâm Edebiyatı́nın Kaynağı Olarak Hadisler". Hz. Muhammed ve Evrensel Mesajı Sempozyumu (20-22 Nisan 2007/Çorum), Çorum: İslâmi İlimler Dergisi Yayınları, 2007, s. 201-211. 
Güngör, Zülfikar. "Türk-İslâm Edebiyatının Kaynağı Olarak Kur'an-ı Kerîm". İslâmî Ilimler Dergisi 1. Kur'an Sempozyumu (14-15 Ekim 2006/Çorum), Çorum: İslâmî Illimler Dergisi Yayınları, 2007, s. 178-188.

Güngör, Zülfikar. Türk Edebiyatında Türkçe Manzûm Hilye-i Nebeviler ve Nesimi Mehmed in Gülistan-ı Şemail 'i. Ankara: Ankara Üniversitesi Sosyal Bilimler Enstitüsü, Doktora Tezi 2000.

HB, HABERBIN. "Word 2016'da Arama Yaparken Joker Karakterler Nasıl Kullanılır". Erişim 2 Mart 2021. http://haberbin.com/word-2016da-arama-yaparken-joker-karakterlernasil-kullanilir

ID, İlim Dergisi . "Illahiyatçının İnternet Kılavuzu”. Erişim 11 Ocak 2021. https://www.ilimdergisi.org/yasayan/ilahiyatcinin-internet-kilavuzu

İslamoğlu, Abdülmecit. Dâvûd-ı Halvetî ve Gülşen-i Tevhîd ü Tahkîk'i (Inceleme-Metin). Bolu: Bolu Araştırmaları Merkezi Yayınları, 2013.

ISNAD, İsnad Atıf Sistemi. "Şamile Eğitimi". Erişim 11 Ocak 2021. https://www.isnadsistemi.org/akademi/samile-egitimi

isTiNYE, İstinyeÜniversitesi."AhmetAtillâŞentürk".Erişim5Ocak2021.https://myisu.istinye. edu.tr/sites/default/files/cv/2019-12/Ahmet\%20Atilla\%20\%c5\%9eent\%c3\%bcrk\%20 -\%20\%c4\%b0ngilizce\%20Y\%c3\%96K\%20Format|\%c4\%b1\%20CV.pdf

İşler, Necati. Muhammed b. İbrahim'in Manzûm Şir'atü'l-Islâm Tercümesi (Şir'a-i Manzûme). (Ankara: Ankara Üniversitesi Sosyal Bilimler Enstitüsü, Doktora Tezi 2021)

IŞLERWEB, Necati İşler'in Kişisel Web sayfası. "Osmanlıca Transkripsiyon Programı”. Erişim 11 Ocak 2021. https://necatiisler.com/tr/2019/04/08/osmanlica-transkripsiyon-programi

IŞLERWEB, Necati İşler'in Kişisel Web Sitesi. “Inebey Kütüphanesi'nde Gülzar-ı Manevi'nin Yeni Bir Nüshası: Sırru'l-Erkan". Erişim 7 Ocak 2021. https://necatiisler.com/ tr/2019/04/08/inebey-kutuphanesindeki-sirrul-erkan-yazmasi-gulzar-i-manevininyeni-bir-nushasidir

işLERWP, Necati İşler'in Kişisel WP sayfası. "İnebey Kütüphanesi'nde Gülzar-ı Manevi'nin Yeni Bir Nüshası: Sırru'I-Erkan". Erişim 8 Ocak 2021. https://necatiisler.wordpress. com/2019/04/08/inebey-kutuphanesindeki-sirrul-erkan-yazmasi-gulzar-i-manevininyeni-bir-nushasidir

IŞLERWP, Necati İşler'in Kişisel WP sayfası. "Osmanlıca Transkripsiyon Programı 3.1". Erişim 11 Ocak 2021. https://necatiisler.files.wordpress.com/2021/02/osmanlica_transkripsiyon_programi_3.1-1.docx

Keleş, Reyhan. Divan Şiirinde Âyet ve Hadis Iktibasları. İstanbul: Kitabevi Yayınları, 2016.

KENZ, "Kenzu'l-Esrâr 06 Hk 6". 10 Ocak 2021. http://www.yazmalar.gov.tr/eser/kenzulesrar/77152

KOOPLOG, Kooplog Blog Platformu. "Dijital Kaynaklar, Dijital Araçlar”. Erişim 2 Aralık 2020. https://www.kooplog.com/dijital-kaynaklardijital-araclar

Köksal, M. Fatih. Eski Türk Edebiyatında Tenkit ve Teori. İstanbul: Kesit Yayınları, 2017.

KTB, Kültür ve Turizm Bakanlığı E-Kitap Arşivi. "Son Eklenen Kitaplar". Erişim 5 Ocak 2021. https://ekitap.ktb.gov.tr; https://ekitap.ktb.gov.tr/TR-78351/edebiyat.html 
Manzûm Tercüme-i Kudûrî. İstanbul: Süleymaniye Kütüphanesi, Fatih Koleksiyonu, 2176.

MANZÛM, Manzûm Terceme-i Şiratü'I-̇̇slâm. “Manzûm Terceme-i Şiratü'l-İslâm Mehmed

B. İbrahim, Muhammed B. İbrahim". Erişim 7 Ocak 2021. https://manzumtercemeisiratulislammehmedbibrahim.wordpress.com

MAYDAN, An Online Publication Of Ali Vural Ak Center For Global Islamic Studies At George Mason University. "Manuscripts - Digital Resources and Projects in Islamic Studies". Erişim 11 Ocak 2021. https://themaydan.com/2019/01/digital-resourcesmanuscripts

MK, T.C. Cumhurbaşkanlığı Millet Kütüphanesi. "Cumhurbaşkanlığı Millet Kütüphanesi Üye Giriş Sayfası". Erişim 5 Ocak 2021. https://kimlik.mk.gov.tr

MK, T.C. Cumhurbaşkanlığı Millet Kütüphanesi. "Nadir Eserler Kütüphanesi". Erişim 10 Ocak 2021. https://mk.gov.tr/icerik/detay/nadir-eserler-kutuphanesi

MN, Metunic - ODTÜ Geliştirme Vakfı Bilgi Teknolojileri A.Ş. "Alan Adı Uygunluğunu Kontrol Et". Erişim 7 Ocak 2021. https://app.metunic.com.tr/order/config/preconfig/ domain

Niyâzî. Mansûr-nâme. nşr. Mustafa Tatcı. İstanbul: MEB Yayınları, 1994.

OAC, Online Archive of California. " Collection of Turkish manuscripts LSC.0896 - Gülsen-i Tevhid", Erişim 7 Ocak 2021. https://oac.cdlib.org/findaid/ark:/13030/c8rx9dg9/ entire_text; http://www.oac.cdlib.org

OAC, Online Archive of California. " Collection of Turkish manuscripts LSC.0896". Erişim 10 Ocak 2021. https://oac.cdlib.org/findaid/ark:/13030/c8rx9dg9/entire_text

OE, Osmanlı Edebiyatı Çalışmaları Bibliyografyası Veritabanı. "Bibliyografya”. Erişim 7 Ocak 2021. https://www.osmanliedebiyati.com/index.htm

OKLAVYE, Osmanlıca Klavye. “OKlavye İle Osmanlıca Yazmaya Başla”. Erişim 11 Ocak 2021. https://www.oklavye.com

Özer, Fatih, "Tarih ve Edebiyat Metinleri Bağlamlı Dizin ve Iş̧levsel Sözlüğü Sistemi (TEBDIZ)". Bilig - Türk Dünyası Sosyal Bilimler Dergisi, 86 (2018), 219-221.

PRINCETON, Princeton University Library Catalog. “Gülistan-ו Şemail”. Erişim 8 Ocak 2021. https://catalog.princeton.edu/catalog/3060657

PRINCETON, Princeton University Library. "Ask a Librarian". Erişim 10 Ocak 2021. https:// library.princeton.edu/help/ask-a-librarian

PRINCETON, Princeton University Library. "Şerh üş-Şemail". Erişim 9 Ocak 2021. https:// catalog.princeton.edu/catalog/5280043

PRINCETON, Princeton University Library. "Your Accounts". 10 Ocak 2021. https://library. princeton.edu/accounts

SARI, İsa Sarı Kişisel Ağ Sayfası. "Geliştirilmiş Osmanlıca/Arapça Klavye". Erişim 11 Ocak 2021. https://www.isa-sari.com/osmanlica

SARI, İsa Sarı Kişisel Ağ Sayfası. “Transkripsiyon”. Erişim 11 Ocak 2021. https://www.isa-sari. com/transkripsiyon

SHAMELA, el-Mektebetü'ş-Şâmile. "Er-Re'isiyye". Erişim 11 Ocak 2021. https://www. shamela.ws 
SÖZLUK, Türk Dil Kurumu Sözlükleri. "Baş Kelimesi - Tarama Sözlüğü". Erişim 15 Şubat 2021. https://sozluk.gov.tr/dosyalar/tarornek/1351_2.gif

TEBDiZ, Tarih ve Edebiyat Metinleri Bağlamlı Dizin ve Iş̧levsel Sözlüğü Sistemi. “Taranan Eeserler". Erişim 15 Şubat 2021. http://www.tebdiz.com/index. php?sayfa=tarananeserler

TEBDiz, Tarih ve Edebiyat Metinleri Bağlamlı Dizin ve İşlevsel Sözlüğü Sistemi. "Hakkımızda". Erişim 15 Şubat 2021. http://www.tebdiz.com/index.php?sayfa=hakkimizda

TEBDiZ, Tarih ve Edebiyat Metinleri Bağlamlı Dizin ve İşlevsel Sözlüğü Sistemi. "Klavuz". Erişim 15 Şubat 2021. http://www.tebdiz.com/index.php?sayfa=klavuz

TEiS, Türk Edebiyatı İsimler Sözlüğü Projesi. "Kapsam”. Erişim 5 Ocak 2021. http://teis. yesevi.edu.tr/kapsam

TEiS, Türk Edebiyatı İsimler Sözlüğü Projesi. "Hayyât Vehbî, Erzincanlı Terzi Baba”. Erişim 9 Ocak 2021. http://teis.yesevi.edu.tr/madde-detay/hayyat-vehbi-erzincanli-terzi-baba

Tepeli, Yusuf. Derviş Muhammed Yemini Fazilet-Name. 2 Cilt. Ankara: Türk Dil Kurumu Yayınları, 2000.

Tulum, Mertol. Tarihî Metin Çalışmalarında Usul. Konya: Çizgi Kitabevi, 2017.

UCLA, University of California Los Angeles Library. "Sign In with your UCLA Logon ID". Erişim 10 Ocak 2021. https://speccoll.library.ucla.edu/aeon/aeon.dll

UCLA, University of California Los Angeles Library. "Research \& Teaching Support". Erişim 10 Ocak 2021. https://www.library.ucla.edu/research-teaching-support/research-help

UK, Ulu Mekatronik. "Microsoft word'de joker karakter kullanımı". Erişim 2 Mart 2021. https://ulumekatronik.blogspot.com/2017/01/microsoft-wordde-joker-karakterkullanm.html

Ünver, İsmail. "Çeviriyazıda Yazım Birliği Üzerine Öneriler". Turkish Studies. 3/6 (2008), s. 1-46.

Yazar, İlyas. "Transkripsiyonlu Metinlerin Web Tabanlı Öğrenme Ortamların Kullanımına Dair Sorunlar ve Çözüm Önerileri". Turkish Studies 3/6 (2008), 733-754.

Yazar, İlyas. "Klâsik Türk Edebiyatı Çalışmalarında Bilişim Teknolojisinden Yararlanma ve E-Kütüphane Uygulamaları". Turkish Studies 2/3 (2007), 572-584.

Yazar, Sadık. "Osmanlı Döneminde Fıkıh Sahasında Yapılmış Türkçe Tercümeler". Türkiye Araştırmaları Literatür Dergisi. 12/23 (2014), 49-166.

YAZMALAR, Türkiye Yazma Eserler Kurumu. "Kâfiye-nâme - Demirbaş No: 06 Hk 33903391". Erişim 8 Ocak 2021. http://www.yazmalar.gov.tr/eser/kafiye-name/40377

YAZMALAR, Türkiye Yazma Eserler Kurumu. "Miftahü'l-Kenz - Demirbaş No: 27 Kilis 3189". Erişim 10 Ocak 2021. http://www.yazmalar.gov.tr/eser/miftahul-kenz/56355

YAZMALAR, Türkiye Yazma Eserler Kurumu. “Terceme-i Şeri'atü'l-İslâm - Demirbaş No: Fıkhı Türkî Talat 68". Erişim 9 Ocak 2021. http://www.yazmalar.gov.tr/eser/tercemei-seriatul-islam/118249

YEK, Türkiye Yazma Eserler Kurumu Başkanlığı. "Yazma Eserler Portalına Ankara'dan Erişim". Erişim 10 Ocak 2021. https://www.yek.gov.tr/Home/Index_?n_id=132

Yılmaz, Mehmet. Edebiyatımızda İslâmî Kaynaklı Sözler. İstanbul: Enderun Kitabevi, 1992. 